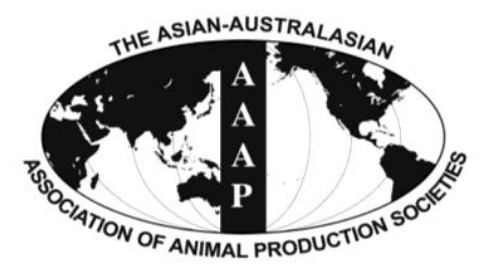

Asian Australas. J. Anim. Sci.

Vol. 26, No. 6 : 845-855 June 2013

http://dx.doi.org/10.5713/ajas.2012.12664

www.ajas.info

pISSN 1011-2367 elSSN 1976-5517

\title{
Growth Performance, Carcass Characteristics and Plasma Mineral Chemistry as Affected by Dietary Chloride and Chloride Salts Fed to Broiler Chickens Reared under Phase Feeding System
}

\author{
M. M. H. Mushtaq ${ }^{1,2, *}$, T. N. Pasha ${ }^{3}$, M. Akram, T. Mushtaq ${ }^{1}$, R. Parvin ${ }^{2}$, \\ H. C. Choi ${ }^{2}$, J. Hwangbo ${ }^{2}$ and J. H. Kim ${ }^{2}$ \\ Department of Poultry Production, University of Veterinary and Animal Sciences, Lahore, 54000, Pakistan
}

\begin{abstract}
Requirements of dietary chloride $(\mathrm{dCl})$ and chloride salts were determined by using $4 \times 2$ factorial arrangement under four phase feeding program. Four levels $(0.31,0.45,0.59$ and $0.73 \%)$ and two sources $\left(\mathrm{NH}_{4} \mathrm{Cl}\right.$ and $\left.\mathrm{CaCl}_{2}\right)$ of the $\mathrm{dCl}$ were allocated to 1,472 chicks in eight dietary treatments in which each treatment was replicated four times with 46 birds per replicate. The four phase feeding program was comprised of four dietary phases: Prestarter (d 1 to 10), Starter (d 11 to 20), Grower (d 21 to 33) and Finisher (d 34 to 42); and diets were separately prepared for each phase. The cations, anions, $\mathrm{pH}$, dissolved oxygen (DO), temperature, electrical conductivity (EC), total dissolved solids (TDS) and salinity were analyzed in drinking water and were not affected by dietary treatments. $\mathrm{BW}$ gain (BWG; $\mathrm{p} \leq 0.009$ ) and feed:gain ( $\mathrm{FG} ; \mathrm{p} \leq 0.03$ ) were improved in $\mathrm{CaCl}_{2}$ supplemented diets during $\mathrm{d} 1$ to 10 . The maximum response of BWG and FG was observed at $0.38 \%$ and $0.42 \% \mathrm{dCl}$, respectively, for d 34 to 42 . However, the level of $\mathrm{dCl}$ for BWG during d 21 to $33(\mathrm{p} \leq 0.04)$ and $\mathrm{d} 34$ to $42(\mathrm{p} \leq 0.009)$ was optimized at $0.60 \%$ and $0.42 \%$, respectively. The level of $\mathrm{dCl}$ for optimized feed intake (FI; $\mathrm{p} \leq 0.006)$ ), FG ( $\mathrm{p} \leq 0.007)$ and litter moisture (LM; $\mathrm{p} \leq 0.001)$ was observed at $0.60 \%, 0.38 \%$ and $0.73 \%$, respectively, for $\mathrm{d}$ 1 to 42 . Water intake (DWI) was not affected by increasing $\mathrm{dCl}$ supplementation ( $\mathrm{p}>0.05)$; however, the ratio between DWI and FI (DWI:FI) was found highest at $0.73 \% \mathrm{dCl}$ during $\mathrm{d} 1$ to $10(\mathrm{p} \leq 0.05)$ and $\mathrm{d} 21$ to 33 ( $\mathrm{p} \leq 0.009)$. Except for $\mathrm{d} 34$ to 42 ( $\mathrm{p} \leq 0.006)$, the increasing level of $\mathrm{dCl}$ did not result in a significant difference in mortality during any phase. Blood $\mathrm{pH}$ and glucose, and breast and thigh weights (percentage of dressed weight) were improved while dressing percentage (DP) and gastrointestinal health were exacerbated with $\mathrm{NH}_{4} \mathrm{Cl}$ as compared to $\mathrm{CaCl}_{2}$ supplemented diets $(\mathrm{p} \leq 0.001)$. Higher plasma $\mathrm{Na}^{+}$and $\mathrm{HCO}_{3}{ }^{-}$and lower $\mathrm{Cl}^{-}$and $\mathrm{Ca}^{++}$ were observed in $\mathrm{NH}_{4} \mathrm{Cl}$ supplemented diets $(\mathrm{p} \leq 0.001)$. Increasing supplementation of $\mathrm{dCl}$ increased plasma $\mathrm{Cl}^{-}(\mathrm{p} \leq 0.04$; quadratically) and linearly reduced plasma $\mathrm{K}^{+}(\mathrm{p} \leq 0.001), \mathrm{Ca}^{++}(\mathrm{p} \leq 0.003), \mathrm{HCO}_{3}^{-}(\mathrm{p} \leq 0.001)$, and $\mathrm{Na}^{+}(\mathrm{p} \leq 0.001$; quadratically). Consequently, higher requirements of dietary chloride are suggested for feed intake; nevertheless, lower levels of dietary chloride are sufficient to support optimal BWG and FG with increasing age. The $\mathrm{NH}_{4} \mathrm{Cl}$ supplemented diets ameliorate breast and thigh meat yield along with overall energy balance (glucose). (Key Words: Chloride, Salt, Growth Performance, Carcass Traits, Plasma Mineral Chemistry, Broiler)
\end{abstract}

\section{INTRODUCTION}

A dynamic relationship exists between cations and anions in order to maintain homeostasis in body fluids.

\footnotetext{
* Corresponding Author: Mirza Muhammad Haroon Mushtaq. Tel: +82-41-580-6728, Fax: +82-41-580-6719, E-mail: haroonuaf @ gmail.com

${ }^{1}$ AgroVisions, Faisalabad, 38800, Pakistan.

${ }^{2}$ Poultry Science Division, National Institute of Animal Science, RDA, 9 Eoryong-ri, Seonghwan-eup, Seobuk-gu, Cheonan-si, Chunngnam-do 331-801, Korea.

${ }^{3}$ Department of Animal Nutrition, University of Veterinary and Animal Sciences, Lahore, 54000, Pakistan.

Submitted Nov. 29, 2012; Accepted Jan. 29, 2013; Revised Mar. 6, 2013
}

Sodium $(\mathrm{Na})$ and potassium $(\mathrm{K})$ serves as major cations while chloride $(\mathrm{Cl})$ and bicarbonate $\left(\mathrm{HCO}_{3}\right)$ represents the anionic nature of these fluids. The cation-anion difference, known as dietary electrolyte balance (DEB; Mongin, 1980) can be described as the changes that occur in the body to achieve normal acid-base balance (ABB). The DEB has been considered as an important factor in broiler diets but becomes more critical when there is a high inclusion proportion of either cation or anion in the diet. Mushtaq et al. (2005 and 2007) keeping in view the concept of Mongin (1980), suggested that a level of $250 \mathrm{mEq} / \mathrm{kg}$ DEB is appropriate to balance cations and anions.

The supplementation of $\mathrm{dCl}$ has been investigated in 
poultry diets according to the age group, environmental conditions (temperature and relative humidity) and dietary composition (protein composition particularly). The National Research Council (NRC, 1994) recommended $0.20 \%$ and $0.15 \% \mathrm{dCl}$ for starter (1 to $3 \mathrm{wk}$ ) and finisher (4 to $6 \mathrm{wk})$ phases of broiler growth, respectively. Under heat stress conditions, the concentration of $\mathrm{Cl}$ ions in the blood increases whereas concentration of $\mathrm{Na}$ and $\mathrm{K}$ decreases causing blood acidification that resulted in low blood electrolyte balance and increased blood $\mathrm{Cl}$ contents (Belay and Teeter, 1993; Borges, 1997; Ahmad et al., 2005). Borges et al. (2004a) found poor performance in birds with blood acidosis when the birds were fed high $\mathrm{Cl}(0.73 \%)$. Mongin and Sauveur (1974) reported a decline in weight gain with an increased level of $\mathrm{dCl}$ (i.e. $0.35,1.01$ and $1.41 \%$ ) when $\mathrm{Na}$ and $\mathrm{K}$ were kept at $0.22 \%$ and $0.39 \%$, respectively.

Various salts have been added to manipulate osmotic balance in broiler chickens and this change leads to changes in water consumption and excretion (Smith and Teeter, 1989; Borges et al., 2004a; b). When calcium chloride $\left(\mathrm{CaCl}_{2}\right)$ is used to supplement $\mathrm{dCl}$ it appears that the $\mathrm{Cl}$ is exchanged with bicarbonate ions in the lower digestive tract to make the whole environment acidic with the excretion of calcium as calcium carbonate (Mongin, 1981). Ahmad et al. (2005) indicated better growth performance and lower $\mathrm{pH}$ with ammonium chloride $\left(\mathrm{NH}_{4} \mathrm{Cl}\right)$ supplementation in heatdistressed broilers. Most of the electrolytic studies were conducted under the high ambient temperature; nevertheless, the current improvement in housing facilities and genetics has necessitated the critical evaluation of the requirements for dietary chloride, DEB and chloride salts in the normal physiological state. Therefore, the present study was envisaged to evaluate the effect of supplementation of dietary chloride with the applicability of the DEB using two chloride salts sources on growth performance, carcass traits, water intake, litter condition and plasma mineral chemistry of fast-growing broiler strain under the phase feeding program.

\section{MATERIALS AND METHODS}

\section{Birds' husbandry}

A total of fourteen hundred and seventy two 1-d old straight-run Hubbard broiler chicks (Hubbard $\times$ Hubbard) were allocated to 8 dietary treatments replicated 4 times in such a way that each replicate had forty six (46) birds. Each replicate pen was equipped with separate overhead, transparent and volume-graduated twenty liter $(20 \mathrm{~L})$ water bottles linked to a nipple drinker line. Water bottles were cleaned and filled with fresh water after measuring the water consumption on a daily basis. One flat bottom round feeder was provided for each experimental pen. Birds were housed in an environmentally controlled system where variation in temperature and relative humidity were recorded and maintained. Continuous light was provided 24 $\mathrm{h}$ for first $3 \mathrm{~d}$ and then $23 \mathrm{~L}: 1 \mathrm{D}$ light pattern was adopted for the rest of the experimental period. A $7.5 \mathrm{~cm}$ deep fresh sawdust was used as litter material over a concrete floor. For the first 3 days, house temperature was maintained at $32^{\circ} \mathrm{C}$ and thereafter reduced by $0.5^{\circ} \mathrm{C}$ per day until $24^{\circ} \mathrm{C}$ was attained at $\mathrm{d} 19$. Birds were vaccinated against Newcastle Disease (ND) plus Infectious Bronchitis viruses at $\mathrm{d} 4$, Infectious Bursal Disease virus at $\mathrm{d} 8$ and again at $\mathrm{d}$ 14; Hydropericardium Syndrome virus at d 18 and NDLasota strain at d 22 following the locally designed vaccination schedule.

\section{Dietary plan}

A basal diet having $\mathrm{dCl}, \mathrm{Na}$ and $\mathrm{K}$ as $0.17,0.30$ and $0.92 \%$, respectively, corresponding to a $\mathrm{DEB}$ value of 320 $\mathrm{mEq} / \mathrm{kg}$ was formulated (Table 1$)$. Four levels of $\mathrm{dCl}(0.31$, $0.45,0.59$ and $0.73 \%$ ) were supplemented to the basal diet with either commercially available feed-grade calcium chloride $\left(\mathrm{CaCl}_{2}\right.$; in powder form, containing $\left.63.9 \% \mathrm{Cl}\right)$ and ammonium chloride $\left(\mathrm{NH}_{4} \mathrm{Cl}\right.$; in granular form, containing $66.3 \% \mathrm{Cl}$ ). The four levels of $\mathrm{dCl}$ corresponded to $\mathrm{DEB}$ values of 280, 240,200, and $160 \mathrm{mEq} / \mathrm{kg}$, respectively.

A large batch of the basal diet was prepared for each phase and the experimental diets were prepared using the basal diet. The experimental period was divided into 4 phases i.e., pre-starter (d 1 to 10), starter (d 11 to 20), grower (d 21 to 33) and finisher (d 34 to 42) according to the recommendations of the Hubbard management guide (Table 1). The nutrient composition was not exactly followed as per the instructions of the Hubbard.

All the ingredients were assayed for their proximate composition (AOAC, 2005) prior to diet formulation and actual values were used in the formulation. The $\mathrm{Na}$ and $\mathrm{K}$ contents of each diet were analyzed by flame photometer (AOAC, 2005) and $\mathrm{Cl}$ by titration with $\mathrm{AgNO}_{3}$ (Lacroix et al., 1970). The $\mathrm{Cl}$, Na and $\mathrm{K}$ content of the final diets were again verified prior to start of the experiment. The analyzed values of the experimental diets were found close to the expected values. The ME of each ingredient was calculated by the appropriate regression equation suggested by NRC (1994). Amino acid composition of each ingredient was calculated using AminoDat ${ }^{\mathrm{TM}}$ 3.0 Platinum (Degussa AG, Germany) based on the DM and CP contents of each ingredient. The amino acid composition of each diet met or exceeded the ideal amino acid ratio suggested by Han and Baker (1994). The experiment lasted for $42 \mathrm{~d}$ of age, offering mash diets throughout the experimental period. 
Table 1. Ingredient composition of the basal diets for different phases of birds fed four levels of chloride with two sources of chloride salts $^{1}$

\begin{tabular}{|c|c|c|c|c|}
\hline Ingredients (\%) & $\begin{array}{l}\text { Pre-starter } \\
\text { (d } 1 \text { to } 10)\end{array}$ & $\begin{array}{c}\text { Starter } \\
\text { (d } 11 \text { to } 20)\end{array}$ & $\begin{array}{c}\text { Grower } \\
\text { (d } 21 \text { to 33) }\end{array}$ & $\begin{array}{l}\text { Finisher } \\
\text { (d } 34 \text { to } 42 \text { ) }\end{array}$ \\
\hline Corn & 30.00 & 19.00 & 10.00 & 36.00 \\
\hline Broken rice & 25.25 & 39.00 & 50.00 & 25.70 \\
\hline Soybean meal & 26.50 & 32.00 & 30.00 & 28.00 \\
\hline Canola meal & 10.00 & 3.25 & - & - \\
\hline Oil (Grease) & 2.85 & 2.00 & 3.00 & 5.75 \\
\hline L-lysine sulphate & 0.60 & 0.29 & 0.23 & 0.16 \\
\hline DL-methionine & 0.33 & 0.29 & 0.25 & 0.23 \\
\hline L-threonine & 0.37 & 0.33 & 0.30 & 0.24 \\
\hline Monocalcium phosphate & 1.70 & 1.75 & 1.62 & 1.52 \\
\hline Limestone & 1.56 & 1.56 & 1.50 & 1.46 \\
\hline $\mathrm{NaCl}$ & 0.21 & 0.19 & 0.18 & 0.20 \\
\hline $\mathrm{K}_{2} \mathrm{CO}_{3}$ & 0.11 & 0.17 & 0.28 & 0.26 \\
\hline Premix $^{2}$ & 0.50 & 0.50 & 0.50 & 0.50 \\
\hline \multicolumn{5}{|c|}{ Nutrients (\% or otherwise stated) } \\
\hline $\mathrm{ME}(\mathrm{kcal} / \mathrm{kg})$ & 2,892 & 3,005 & 3,099 & 3,176 \\
\hline Crude protein & 20.97 & 20.06 & 19.08 & 18.27 \\
\hline Calcium & 1.00 & 0.95 & 0.90 & 0.87 \\
\hline Available phos. & 0.45 & 0.45 & 0.42 & 0.40 \\
\hline Sodium & 0.30 & 0.30 & 0.30 & 0.30 \\
\hline Potassium & 0.92 & 0.92 & 0.92 & 0.92 \\
\hline Chloride & 0.17 & 0.17 & 0.17 & 0.17 \\
\hline $\mathrm{DEB}(\mathrm{mEq} / \mathrm{kg})^{3}$ & 317 & 319 & 320 & 319 \\
\hline
\end{tabular}

\footnotetext{
${ }^{1}$ All the diets were supplemented with 4 levels of either $\mathrm{CaCl}_{2}(0.11,0.22,0.33$ or $0.44 \%)$ or $\mathrm{NH}_{4} \mathrm{Cl}(0.105,0.21,0.315$ or $0.42 \%)$ to make final $\mathrm{Cl}$ concentrations of $0.31,0.45,0.59$ or $0.73 \%$, respectively. The basal diet has $0.17 \% \mathrm{Cl}$ in it. The concentration of calcium in dietary treatments has been adjusted by excluding monocalcium phosphate.

${ }^{2}$ Provides per $\mathrm{kg}$ of finished diet: vitamin $\mathrm{A}, 12 \mathrm{mg}$; vitamin $\mathrm{D}_{3}, 7 \mathrm{mg}$; vitamin $\mathrm{E}, 100 \mathrm{mg}$; vitamin $\mathrm{K}_{3}\left(50 \%\right.$ as menadione), $3 \mathrm{mg}$; vitamin $\mathrm{B}_{1}(98 \%), 3$ $\mathrm{mg}$; vitamin $\mathrm{B}_{2}(800,000 \mathrm{mg}), 12 \mathrm{mg}$; vitamin $\mathrm{B}_{3}$ (niacin; $\left.99 \%\right), 600 \mathrm{mg}$; vitamin $\mathrm{B}_{6}(98 \%), 4 \mathrm{mg}$; vitamin $\mathrm{B}_{9}$ (folic acid; $\left.95 \%\right), 2 \mathrm{mg}$; vitamin $\mathrm{B}_{12}$ (0.10\%), 20 mg; Biotin (0.10\%), 5 mg; Ca-Pentothenate (98\%), $12 \mathrm{mg}$; cholin (70\% as choline chloride), $1 \mathrm{~g} ; \mathrm{MnO}(60 \%), 169 \mathrm{mg} ; \mathrm{FeSO} 4$ (21\%), 200 $\mathrm{mg} ; \mathrm{ZnSO}_{4}(36 \%), 150 \mathrm{mg} ; \mathrm{CuSO}_{4}(25 \%), 40 \mathrm{mg}$; Se (sodium selenite 0.40\%), $100 \mathrm{mg}$; KI (68\%), 2 mg; Salinomycin, $60 \mathrm{mg}$; Zinc bacitracin (as Albac $10 \%), 50 \mathrm{mg}$.

${ }^{3}$ DEB $($ Dietary electrolyte balance $)=(\% \mathrm{Na} \times 10,000 / 23)+(\% \mathrm{~K} \times 10,000 / 39.1)-(\% \mathrm{Cl} \times 10,000 / 35.5)$.
}

\section{Data collection}

Live performance: Data on feed intake (FI), BW gain (BWG) and feed-to-gain ratio (FG) was recorded for each phase. The feed was withheld for six hrs before weighing the birds at the end of each phase to ensure the emptying of the digestive tract of the bird. Water intake (DWI) was recorded on a daily basis and a ratio between DWI to FI (DWI:FI) was also calculated for each phase. Mortality was recorded on a daily basis and dead birds were weighed prior to removal to correct FG.

Litter moisture: Litter was collected at the end of each phase to determine its moisture (LM). For this purpose, about $500 \mathrm{~g}$ litter sample was randomly collected from different locations in each replicate pen. Each sample was homogenized, a representative sample of $100 \mathrm{~g}$ was taken, and oven dried at $105^{\circ} \mathrm{C}$ for $24 \mathrm{~h}$ (AOAC, 2005) to determine moisture contents.

Water analysis: Water was analyzed for its $\mathrm{pH}$ by $\mathrm{pH}$ metre (LT-Lutron pH-207 Taiwan), dissolved oxygen (DO) by DO metre (YSI 55 Incorporated, Yellow Springs, Ohio, 4387, USA). Moreover, temperature, electrical conductivity (EC), total dissolved solids (TDS) and salinity were recorded by the Combo meter (H M Digital, Inc. CA 90230). These observations were recorded twice (morning and noon) daily from different replicates.

Carcass, blood and plasma mineral responses: At the end of $42 \mathrm{~d}$, two birds were randomly selected from each replicate for carcass and plasma mineral responses. Blood was collected from the wing vein in an EDTA-coated vacutainer for immediate $\mathrm{pH}$ monitoring and for blood glucose. Blood plasma was separated by centrifugation of blood samples at 2,000 $\times$ g for 15 min (Hayat et al., 1999; Ahmad et al., 2005) and was analyzed for mineral (Cl, Na, $\mathrm{K}, \mathrm{Ca}, \mathrm{P}, \mathrm{Mg}, \mathrm{HCO}_{3}$ ) contents. The same birds were further used for evaluation of carcass characteristics. Carcass responses were evaluated in terms of dressing (\% of live 
weight), breast, thigh, intestine, proventriculus and gizzard weights ( $\%$ of dressed weight).

\section{Statistical analyses}

The experiment was executed under completely randomized design with $4 \times 2$ factorial arrangement using 4 levels of $\mathrm{dCl}$ from 2 sources of salt. Each pen mean was an experimental unit. The data obtained at the end of the experiment were subjected to ANOVA technique using GLM of Minitab 15.1 (Minitab Inc., State College PA) where linear, quadratic and cubic terms were studied in the model using polynomial contrasts. The level of significance was 0.05 unless or otherwise stated.

\section{RESULTS AND DISCUSSION}

The drinking water was analyzed daily for its EC (1.06 to 1.39$)$, TDS (1,010 to 1,234$), \mathrm{pH}$ (7.17 to 7.49$)$, salinity (0.8 to 1.0$)$, DO (3.41 to 5.10$)$ and temperature (24.4 to 33.1 , keeping in view the concept that these water characteristics and concentration of the minerals (cations plus anions) could maneuver the DEB of ingesta (Teeter and Smith, 1986; Borges et al., 2003a, b). The water $\mathrm{pH}$ values were found within the normal range (6.0 to 8.5) that has been considered as optimal for broiler performance (Socha et al., 2002; Borges et al., 2003a, b). Moreover, the water TDS levels between 1000-3000 ppm are considered satisfactory for broilers (Chiba, 2009).

The response of $\mathrm{dCl}$ on $\mathrm{BWG}$ in different phases is presented in Table 2. A highly significant rise in $\mathrm{BWG}$ $(\mathrm{p} \leq 0.009)$ was observed by replacing $\mathrm{NH}_{4} \mathrm{Cl}$ with $\mathrm{CaCl}_{2}$ during 1 to $10 \mathrm{~d}$ of age. During d 11 to 20, a linear drop in BWG was noticed with increasing supplementation of $\mathrm{dCl}$ $(\mathrm{p} \leq 0.05)$. Significant cubic response in $\mathrm{BWG}$ was observed during d 21 to $33(\mathrm{p} \leq 0.04)$ and d 34 to $42(\mathrm{p} \leq 0.009)$. When optimized, maximum BWG (i.e. 702 and 579) was observed in $0.60 \%(\mathrm{DEB}=197 \mathrm{mEq} / \mathrm{kg})$ and $0.42 \%(\mathrm{DEB}=248$ $\mathrm{mEq} / \mathrm{kg}) \mathrm{dCl}$, associated with the regression equation for $\mathrm{d}$ 21 to $33\left(\mathrm{BWG}=924.8-1,770 \mathrm{Cl}+3,983 \mathrm{Cl}^{2}-2,755 \mathrm{Cl}^{3}\right)$ and d 34 to $42\left(\mathrm{BWG}=-2,106+16,130 \mathrm{Cl}-31,222 \mathrm{Cl}^{2}+19,138\right.$ $\mathrm{Cl}^{3}$ ), respectively. It is clear from these results that with increasing age, the requirements for $\mathrm{dCl}$ decreased and

Table 2. Effect of dietary chloride and chloride salts on body weight gain of broilers during various phases of the experiment

\begin{tabular}{|c|c|c|c|c|c|}
\hline Item & d 1-10 & d 11-20 & d 21-33 & d 34-42 & d $1-42$ \\
\hline \multicolumn{6}{|l|}{ Dietary $\mathrm{Cl}(\%)$} \\
\hline 0.31 & 135 & 340 & 677 & 464 & 1,615 \\
\hline 0.45 & 130 & 336 & 684 & 574 & 1,724 \\
\hline 0.59 & 131 & 329 & 701 & 473 & 1,633 \\
\hline 0.73 & 138 & 320 & 683 & 476 & 1,618 \\
\hline \multicolumn{6}{|l|}{ Salts } \\
\hline $\mathrm{CaCl}_{2}$ & 138 & 337 & 690 & 488 & 1,653 \\
\hline $\mathrm{NH}_{4} \mathrm{Cl}$ & 129 & 326 & 682 & 505 & 1,642 \\
\hline \multicolumn{6}{|l|}{$\mathrm{Cl} \times$ Salts } \\
\hline $0.31 \times \mathrm{CaCl}_{2}$ & 138 & 352 & 708 & 455 & 1,653 \\
\hline $0.45 \times \mathrm{CaCl}_{2}$ & 140 & 340 & 666 & 608 & 1,753 \\
\hline $0.59 \times \mathrm{CaCl}_{2}$ & 132 & 332 & 723 & 386 & 1,574 \\
\hline $0.73 \times \mathrm{CaCl}_{2}$ & 142 & 324 & 664 & 502 & 1,631 \\
\hline $0.31 \times \mathrm{NH}_{4} \mathrm{Cl}$ & 132 & 329 & 645 & 473 & 1,578 \\
\hline $0.45 \times \mathrm{NH}_{4} \mathrm{Cl}$ & 121 & 332 & 702 & 540 & 1,695 \\
\hline $0.59 \times \mathrm{NH}_{4} \mathrm{Cl}$ & 129 & 326 & 679 & 559 & 1,693 \\
\hline $0.73 \times \mathrm{NH}_{4} \mathrm{Cl}$ & 135 & 317 & 703 & 449 & 1,604 \\
\hline RMSE & 3.1 & 7.9 & 16.1 & 35.6 & 43.1 \\
\hline \multicolumn{6}{|l|}{ ANOVA } \\
\hline $\mathrm{Cl}$ & 0.427 & 0.049 & 0.451 & 0.592 & 0.306 \\
\hline $\mathrm{Cl}_{\mathrm{L}}$ & 0.443 & 0.065 & 0.655 & 0.699 & 0.620 \\
\hline $\mathrm{Cl}_{\mathrm{Q}}$ & 0.056 & 0.782 & 0.508 & 0.165 & 0.111 \\
\hline $\mathrm{Cl}_{\mathrm{C}}$ & 0.824 & 0.981 & 0.043 & 0.009 & 0.115 \\
\hline Salt & 0.009 & 0.171 & 0.658 & 0.647 & 0.787 \\
\hline Salt $\times C l$ & 0.518 & 0.486 & 0.183 & 0.929 & 0.347 \\
\hline
\end{tabular}

$\mathrm{Cl}_{\mathrm{L},} \mathrm{Cl}_{\mathrm{Q}}$ and $\mathrm{Cl}_{\mathrm{C}}$ are linear, quadratic and cubic terms for $\mathrm{Cl}$, respectively $(\mathrm{df}=24)$.

Number of observations per mean value $=46$ birds $\times 4$ replicates $=184$ birds . 
DEB increased as the $\mathrm{dCl}$ was dropped from $0.73 \%$ (DEB = $160 \mathrm{mEq} / \mathrm{kg}$; $\mathrm{d} 1$ to 10$)$ to $0.60 \%$ (DEB $=197 \mathrm{mEq} / \mathrm{kg} ; \mathrm{d} 21$ to 33 ) and then to $0.42 \%$ (DEB $=248 \mathrm{mEq} / \mathrm{kg}$; d 34 to 42 ). This drop in elemental requirements of the $\mathrm{dCl}$ is in accordance with the recommendations of NRC (1994) but the numerical value is quite high in our experiment. This might be due to the fact that the levels recommended by NRC (1994) were determined using Vantress $\times$ White Plymouth Rock (Oliveira et al., 2005) which had more potential for mass and skeletal development than the fastgrowing strains of today's broiler. Secondly, the $\mathrm{dCl}$ requirements have not been investigated using four phases of the broiler's life before this experiment. Murakami et al. (1997) in recent studies supported the view that the requirements of $\mathrm{Na}$ and $\mathrm{Cl}$ are increasing. Further, the higher levels of these minerals did not appear to restrict growth effects in terms of body weight and feed efficiency. It can be suggested from these observations that the requirements for $\mathrm{dCl}$ are higher than the previously mentioned levels and the role of dietary salt is not as important for growth performance if it does not change the rest of the nutrient formulations.

Cubic $(\mathrm{p} \leq 0.006)$ responses were observed for FI for the period of $\mathrm{d} 1$ to 42 (Table 3) however, maximum intake was achieved at $0.60 \% \mathrm{dCl}(\mathrm{DEB}=197 \mathrm{mEq} / \mathrm{kg})$ when optimized using regression equation ( $\mathrm{FI}=3,629-1,485 \mathrm{Cl}+$ $5,128 \mathrm{Cl}^{2}-4,297 \mathrm{Cl}^{3}$ ). This means that the appetite of birds is satisfied up to a certain extent and after that, bird excretes excessive $\mathrm{Cl}$ in order to maintain acid-base balance. The direct impact of $\mathrm{dCl}$ on appetite has been noticed in previous experiments that suggest better FI by increasing $\mathrm{Na}$ and $\mathrm{Cl}$ (Branton, 1986; Murakami et al., 1997; El-Deek, et al., 2010). However, in the present study it is considered that the negative effects of higher $\mathrm{dCl}$ on growth parameters may be compensated by higher levels of both $\mathrm{Na}$ and $\mathrm{K}$. Further, the cation-anion ratio has a strong impact on acidbase balance in broilers and a blood pH of 7.28 (Hurwitz et al., 1973) has been considered as ideal for maximum growth efficiency which is also evident from the present study. Additional research data are required to fully determine the precise requirement of individual electrolytes, especially chloride. However, as far as the phenomenon of

Table 3. Effect of dietary chloride and chloride salts on feed intake of broilers during various phases of the experiment

\begin{tabular}{|c|c|c|c|c|c|}
\hline Item & d 1-10 & d 11-20 & d 21-33 & d 34-42 & d $1-42$ \\
\hline \multicolumn{6}{|l|}{ Dietary $\mathrm{Cl}(\%)$} \\
\hline 0.31 & 221 & 516 & 1,678 & 1,118 & 3,534 \\
\hline 0.45 & 211 & 506 & 1,626 & 1,265 & 3,608 \\
\hline 0.59 & 207 & 516 & 1,717 & 1,216 & 3,656 \\
\hline 0.73 & 230 & 504 & 1,598 & 1,274 & 3,606 \\
\hline \multicolumn{6}{|l|}{ Salts } \\
\hline $\mathrm{CaCl}_{2}$ & 217 & 498 & 1,663 & 1,233 & 3,612 \\
\hline $\mathrm{NH}_{4} \mathrm{Cl}$ & 218 & 523 & 1,646 & 1,203 & 3,590 \\
\hline \multicolumn{6}{|l|}{$\mathrm{Cl} \times$ Salts } \\
\hline $0.31 \times \mathrm{CaCl}_{2}$ & 212 & 512 & 1,669 & 1,150 & 3,544 \\
\hline $0.45 \times \mathrm{CaCl}_{2}$ & 215 & 492 & 1,546 & 1,237 & 3,490 \\
\hline $0.59 \times \mathrm{CaCl}_{2}$ & 203 & 489 & 1,832 & 1,283 & 3,807 \\
\hline $0.73 \times \mathrm{CaCl}_{2}$ & 238 & 498 & 1,608 & 1,264 & 3,607 \\
\hline $0.31 \times \mathrm{NH}_{4} \mathrm{Cl}$ & 229 & 520 & 1,687 & 1,087 & 3,523 \\
\hline $0.45 \times \mathrm{NH}_{4} \mathrm{Cl}$ & 207 & 520 & 1,706 & 1,293 & 3,726 \\
\hline $0.59 \times \mathrm{NH}_{4} \mathrm{Cl}$ & 211 & 543 & 1,602 & 1,148 & 3,504 \\
\hline $0.73 \times \mathrm{NH}_{4} \mathrm{Cl}$ & 223 & 510 & 1,588 & 1,284 & 3,605 \\
\hline RMSE & 8.3 & 27.0 & 32.2 & 41.6 & 63.7 \\
\hline \multicolumn{6}{|l|}{ ANOVA } \\
\hline $\mathrm{Cl}$ & 0.245 & 0.381 & 0.918 & 0.266 & 0.721 \\
\hline $\mathrm{Cl}_{\mathrm{L}}$ & 0.486 & 0.818 & 0.373 & 0.059 & 0.324 \\
\hline $\mathrm{Cl}_{\mathrm{Q}}$ & 0.055 & 0.974 & 0.378 & 0.272 & 0.306 \\
\hline $\mathrm{Cl}_{\mathrm{C}}$ & 0.546 & 0.722 & 0.142 & 0.098 & 0.006 \\
\hline Salt & 0.953 & 0.343 & 0.635 & 0.447 & 0.709 \\
\hline Salt $\times C l$ & 0.296 & 0.871 & 0.142 & 0.873 & 0.368 \\
\hline
\end{tabular}

$\mathrm{Cl}_{\mathrm{L},} \mathrm{Cl}_{\mathrm{Q}}$ and $\mathrm{Cl}_{\mathrm{C}}$ are linear, quadratic and cubic terms for $\mathrm{Cl}$, respectively $(\mathrm{df}=24)$.

Number of observations per mean value $=46$ birds $\times 4$ replicates $=184$ birds . 
feed intake is concerned, the manipulation of DEB may assist it as by increasing DEB the intake also increased and that might adjust blood electrolytes and the acid base balance. Neither sources nor interaction effects were observed to play a role in FI during the whole experimental period.

Except during pre-starter phase, there was no difference in FG brought about by replacing $\mathrm{NH}_{4} \mathrm{Cl}$ with $\mathrm{CaCl}_{2}$ during the rest of the experimental period ( $\mathrm{p} \leq 0.03$; Table 4$)$. The higher $\mathrm{BWG}$ in the $\mathrm{CaCl}_{2}$ supplemented diets showed that birds efficiently utilized feed during d 1 to 10 . However, marked effects (cubic responses) of the $\mathrm{dCl}$ were noticed in FG during the finisher $(p \leq 0.004)$ and overall $(p \leq 0.007)$ periods. Upon optimization, improved FG was observed at $0.38 \% \mathrm{dCl}(\mathrm{DEB}=259 \mathrm{mEq} / \mathrm{kg})$ for finisher $(2.15)$ and overall (1.92) periods, respectively. Increasing the level of $\mathrm{dCl}$ exacerbated lysine-arginine antagonism, which alters the acid base balance in birds (Kim et al., 1989) and that might be the reason for the poor $\mathrm{FG}$ at higher $\mathrm{dCl}$ supplementation in the present study. It is clear that the

Table 4. Effect of dietary chloride and chloride salts on feed:gain of broilers during various phases of the experiment

\begin{tabular}{|c|c|c|c|c|c|}
\hline Item & d $1-10$ & d $11-20$ & d 21-33 & d 34-42 & d 1-42 \\
\hline & & & $-\mathrm{g} /$ & & \\
\hline \multicolumn{6}{|l|}{ Dietary $\mathrm{Cl}(\%)$} \\
\hline 0.31 & 1.63 & 1.53 & 2.52 & 2.50 & 2.05 \\
\hline 0.45 & 1.63 & 1.51 & 2.38 & 2.24 & 1.94 \\
\hline 0.59 & 1.59 & 1.57 & 2.45 & 2.88 & 2.12 \\
\hline 0.73 & 1.67 & 1.58 & 2.34 & 2.75 & 2.08 \\
\hline \multicolumn{6}{|l|}{ Salts } \\
\hline $\mathrm{CaCl}_{2}$ & 1.57 & 1.48 & 2.41 & 2.72 & 2.05 \\
\hline $\mathrm{NH}_{4} \mathrm{Cl}$ & 1.68 & 1.61 & 2.43 & 2.47 & 2.05 \\
\hline \multicolumn{6}{|l|}{$\mathrm{Cl} \times$ Salts } \\
\hline $0.31 \times \mathrm{CaCl}_{2}$ & 1.53 & 1.47 & 2.36 & 2.70 & 2.01 \\
\hline $0.45 \times \mathrm{CaCl}_{2}$ & 1.54 & 1.45 & 2.33 & 2.04 & 1.84 \\
\hline $0.59 \times \mathrm{CaCl}_{2}$ & 1.54 & 1.47 & 2.54 & 3.50 & 2.26 \\
\hline $0.73 \times \mathrm{CaCl}_{2}$ & 1.68 & 1.54 & 2.43 & 2.64 & 2.07 \\
\hline $0.31 \times \mathrm{NH}_{4} \mathrm{Cl}$ & 1.74 & 1.58 & 2.68 & 2.31 & 2.08 \\
\hline $0.45 \times \mathrm{NH}_{4} \mathrm{Cl}$ & 1.71 & 1.58 & 2.43 & 2.44 & 2.04 \\
\hline $0.59 \times \mathrm{NH}_{4} \mathrm{Cl}$ & 1.63 & 1.67 & 2.36 & 2.26 & 1.98 \\
\hline $0.73 \times \mathrm{NH}_{4} \mathrm{Cl}$ & 1.65 & 1.61 & 2.26 & 2.87 & 2.10 \\
\hline RMSE & 0.045 & 0.092 & 0.067 & 0.179 & 0.068 \\
\hline ANOVA & --------- & --------- & Probabil & ty ------. & --------- \\
\hline $\mathrm{Cl}$ & 0.666 & 0.143 & 0.576 & 0.056 & 0.067 \\
\hline $\mathrm{Cl}_{\mathrm{L}}$ & 0.810 & 0.593 & 0.217 & 0.179 & 0.295 \\
\hline $\mathrm{Cl}_{\mathrm{Q}}$ & 0.359 & 0.899 & 0.853 & 0.109 & 0.577 \\
\hline $\mathrm{Cl}_{\mathrm{C}}$ & 0.474 & 0.744 & 0.290 & 0.004 & 0.007 \\
\hline Salt & 0.034 & 0.142 & 0.784 & 0.280 & 0.966 \\
\hline Salt $\times C l$ & 0.069 & 0.943 & 0.022 & 0.911 & 0.295 \\
\hline
\end{tabular}

$\mathrm{Cl}_{\mathrm{L}}, \mathrm{Cl}_{\mathrm{Q}}$ and $\mathrm{Cl}_{\mathrm{C}}$ are linear, quadratic and cubic terms for $\mathrm{Cl}$, respectively $(\mathrm{df}=24)$.

Number of observations per mean value $=46$ birds $\times 4$ replicates $=184$ birds. amount of the $\mathrm{dCl}$ is not directly responsible for changes in the growth efficiency of chicks and the requirements of the $\mathrm{dCl}$ are different for different growth parameters like BWG, FI and FG. It was evident that sources play a pivotal role in growth performance during initial days of life while after that birds become more sensitive to the amount of $\mathrm{dCl}$. No other study has yet been carried out to evaluate $\mathrm{dCl}$ requirements during the phase feeding program consequently this finding indicates there is need to establish the biochemical processes involved in the different phases of broiler life.

Neither amount, source nor interaction responses were observed on DWI during the whole experimental period ( $p>0.05$, Table 5). The ratio between DWI and FI (DWI:FI) was significantly affected by source and level interaction for $\mathrm{d} 1$ to $10(\mathrm{p} \leq 0.05$, Table 6$)$. At the highest level of $\mathrm{dCl}$ (i.e. $0.73 \%$ ), DWI:FI was found lowest in $\mathrm{CaCl}_{2}$ supplemented diets and highest in $\mathrm{NH}_{4} \mathrm{Cl}$ supplemented diets. The numerical value of DWI:FI ranged from 1.88 to 2.85 which is higher than the previously observed values

Table 5. Effect of dietary chloride and chloride salts on water intake of broilers during various phases of the experiment

\begin{tabular}{|c|c|c|c|c|c|}
\hline Item & d 1-10 & d 11-20 & d 21-33 & d 34-42 & d 1-42 \\
\hline & & & - ml & 政 & 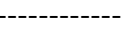 \\
\hline \multicolumn{6}{|l|}{ Dietary $\mathrm{Cl}(\%)$} \\
\hline 0.31 & 534 & 1,108 & 3,705 & 2,478 & 7,824 \\
\hline 0.45 & 484 & 1,138 & 3,807 & 2,420 & 7,848 \\
\hline 0.59 & 488 & 1,091 & 3,650 & 2,479 & 7,708 \\
\hline 0.73 & 579 & 1,101 & 3,781 & 2,587 & 8,047 \\
\hline \multicolumn{6}{|l|}{ Salts } \\
\hline $\mathrm{CaCl}_{2}$ & 510 & 1,107 & 3,733 & 2,499 & 7,848 \\
\hline $\mathrm{NH}_{4} \mathrm{Cl}$ & 533 & 1,111 & 3,739 & 2,482 & 7,866 \\
\hline \multicolumn{6}{|l|}{$\mathrm{Cl} \times$ Salts } \\
\hline $0.31 \times \mathrm{CaCl}_{2}$ & 535 & 1,083 & 3,808 & 2,443 & 7,870 \\
\hline $0.45 \times \mathrm{CaCl}_{2}$ & 508 & 1,105 & 3,742 & 2,434 & 7,789 \\
\hline $0.59 \times \mathrm{CaCl}_{2}$ & 466 & 1,140 & 3,633 & 2,496 & 7,735 \\
\hline $0.73 \times \mathrm{CaCl}_{2}$ & 528 & 1,100 & 3,748 & 2,623 & 7,998 \\
\hline $0.31 \times \mathrm{NH}_{4} \mathrm{Cl}$ & 533 & 1,132 & 3,601 & 2,512 & 7,779 \\
\hline $0.45 \times \mathrm{NH}_{4} \mathrm{Cl}$ & 460 & 1,170 & 3,873 & 2,405 & 7,907 \\
\hline $0.59 \times \mathrm{NH}_{4} \mathrm{Cl}$ & 511 & 1,042 & 3,668 & 2,462 & 7,682 \\
\hline $0.73 \times \mathrm{NH}_{4} \mathrm{Cl}$ & 630 & 1,102 & 3,814 & 2,550 & 8,096 \\
\hline RMSE & 22.2 & 44.2 & 73.3 & 101.1 & 132.1 \\
\hline \multicolumn{6}{|l|}{ ANOVA } \\
\hline $\mathrm{Cl}$ & 0.757 & 0.652 & 0.071 & 0.067 & 0.061 \\
\hline $\mathrm{Cl}_{\mathrm{L}}$ & 0.184 & 0.694 & 0.826 & 0.310 & 0.465 \\
\hline $\mathrm{Cl}_{\mathrm{Q}}$ & 0.059 & 0.798 & 0.848 & 0.327 & 0.332 \\
\hline $\mathrm{Cl}_{\mathrm{C}}$ & 0.759 & 0.443 & 0.101 & 0.855 & 0.375 \\
\hline Salt & 0.306 & 0.907 & 0.932 & 0.843 & 0.911 \\
\hline Salt $\times \mathrm{Cl}$ & 0.059 & 0.386 & 0.271 & 0.567 & 0.785 \\
\hline
\end{tabular}

$\overline{\mathrm{Cl}_{\mathrm{L}}, \mathrm{Cl}_{\mathrm{Q}} \text { and } \mathrm{Cl}_{\mathrm{C}} \text { are linear, quadratic and cubic terms for } \mathrm{Cl} \text {, respectively }}$ $(\mathrm{df}=24)$.

Number of observations per mean value $=46$ birds $\times 4$ replicates $=184$ birds. 
Table 6. Effect of dietary chloride and chloride salts on water intake-to-feed intake ratio of broilers during various phases of the experiment

\begin{tabular}{|c|c|c|c|c|c|}
\hline Item & d 1-10 & d 11-20 & $\mathrm{d} 21-33$ & d 34-42 & $\mathrm{d} 1-42$ \\
\hline & \multicolumn{5}{|c|}{ 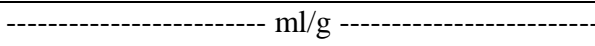 } \\
\hline \multicolumn{6}{|l|}{ Dietary $\mathrm{Cl}(\%)$} \\
\hline 0.31 & 2.45 & 2.20 & 2.21 & 2.24 & 2.22 \\
\hline 0.45 & 2.32 & 2.27 & 2.36 & 1.93 & 2.18 \\
\hline 0.59 & 2.40 & 2.16 & 2.14 & 2.05 & 2.11 \\
\hline 0.73 & 2.55 & 2.21 & 2.37 & 2.04 & 2.23 \\
\hline \multicolumn{6}{|l|}{ Salts } \\
\hline $\mathrm{CaCl}_{2}$ & 2.38 & 2.25 & 2.26 & 2.04 & 2.18 \\
\hline $\mathrm{NH}_{4} \mathrm{Cl}$ & 2.48 & 2.16 & 2.28 & 2.09 & 2.20 \\
\hline \multicolumn{6}{|l|}{$\mathrm{Cl} \times$ Salts } \\
\hline $0.31 \times \mathrm{CaCl}_{2}$ & 2.57 & 2.13 & 2.28 & 2.14 & 2.22 \\
\hline $0.45 \times \mathrm{CaCl}_{2}$ & 2.41 & 2.26 & 2.45 & 1.98 & 2.24 \\
\hline $0.59 \times \mathrm{CaCl}_{2}$ & 2.30 & 2.40 & 1.99 & 1.95 & 2.03 \\
\hline $0.73 \times \mathrm{CaCl}_{2}$ & 2.24 & 2.23 & 2.33 & 2.09 & 2.22 \\
\hline $0.31 \times \mathrm{NH}_{4} \mathrm{Cl}$ & 2.34 & 2.27 & 2.14 & 2.35 & 2.22 \\
\hline $0.45 \times \mathrm{NH}_{4} \mathrm{Cl}$ & 2.23 & 2.28 & 2.27 & 1.88 & 2.13 \\
\hline $0.59 \times \mathrm{NH}_{4} \mathrm{Cl}$ & 2.49 & 1.92 & 2.29 & 2.16 & 2.19 \\
\hline $0.73 \times \mathrm{NH}_{4} \mathrm{Cl}$ & 2.85 & 2.19 & 2.41 & 1.99 & 2.25 \\
\hline RMSE & 0.122 & 0.099 & 0.055 & 0.103 & 0.070 \\
\hline ANOVA & \multicolumn{5}{|c|}{ 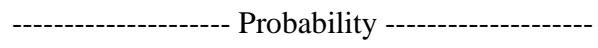 } \\
\hline $\mathrm{Cl}$ & 0.713 & 0.275 & 0.279 & 0.625 & 0.243 \\
\hline $\mathrm{Cl}_{\mathrm{L}}$ & 0.639 & 0.887 & 0.371 & 0.258 & 0.906 \\
\hline $\mathrm{Cl}_{\mathrm{Q}}$ & 0.403 & 0.924 & 0.527 & 0.122 & 0.192 \\
\hline $\mathrm{Cl}_{\mathrm{C}}$ & 0.860 & 0.541 & 0.009 & 0.189 & 0.388 \\
\hline Salt & 0.556 & 0.482 & 0.814 & 0.552 & 0.767 \\
\hline Salt $\times \mathrm{Cl}$ & 0.048 & 0.384 & 0.062 & 0.482 & 0.457 \\
\hline
\end{tabular}

$\mathrm{Cl}_{\mathrm{L}}, \mathrm{Cl}_{\mathrm{Q}}$ and $\mathrm{Cl}_{\mathrm{C}}$ are linear, quadratic and cubic terms for $\mathrm{Cl}$, respectively $(\mathrm{df}=24)$.

Number of observations per mean value $=46$ birds $\times 4$ replicates $=184$ birds.

(i.e. 1.6 to 2.0; Dozier et al., 2002; Singleton et al., 2004). In the current study the supplementation of minerals not only stimulated water intake, but also adjusted mineral losses. Further, the higher water intake might neutralize the high acidic condition caused by the increased supplementation of the $\mathrm{dCl}$. A cubic response was observed in DWI:FI during d 21 to $33(\mathrm{p} \leq 0.009)$ and found to be highest at $0.73 \% \mathrm{dCl}$. It is clear that this ratio was affected by the numerical change in FI during this phase. Ahmad et al. (2005) and Mushtaq et al. (2005, 2007) observed no response of $\mathrm{dCl}$ on DWI:FI when comparing different levels, electrolytes or salts, respectively.

Increasing supplementation of $\mathrm{dCl} \quad(\mathrm{p} \leq 0.04)$ and replacing $\mathrm{NH}_{4} \mathrm{Cl}$ with $\mathrm{CaCl}_{2}(\mathrm{p} \leq 0.001)$ aggravated the litter moisture condition during $\mathrm{d} 1$ to 42 (Table 7). Likewise, Pesti et al. (1999), Murakami et al. (2003) and Mushtaq et al. $(2005,2007)$ supports our finding. It is anticipated that poultry litter wetness could be affected by dietary nutrients (mainly electrolytes), health of gastrointestinal tract (GIT),
Table 7. Effect of dietary chloride and chloride salts on litter moisture of broilers during various phases of the experiment

\begin{tabular}{|c|c|c|c|c|c|}
\hline Item & d 1-10 & d 11-20 & d 21-33 & d 34-42 & d 1-42 \\
\hline \multicolumn{6}{|l|}{ Dietary $\mathrm{Cl}(\%)$} \\
\hline 0.31 & 15.85 & 37.87 & 33.57 & 32.28 & 29.89 \\
\hline 0.45 & 14.35 & 35.37 & 44.30 & 40.98 & 33.75 \\
\hline 0.59 & 15.23 & 36.55 & 56.87 & 40.97 & 34.91 \\
\hline 0.73 & 13.26 & 36.07 & 55.12 & 35.04 & 34.87 \\
\hline \multicolumn{6}{|l|}{ Salts } \\
\hline $\mathrm{CaCl}_{2}$ & 14.75 & 41.28 & 49.79 & 36.47 & 35.57 \\
\hline $\mathrm{NH}_{4} \mathrm{Cl}$ & 14.60 & 31.65 & 40.15 & 38.16 & 31.14 \\
\hline \multicolumn{6}{|l|}{$\mathrm{Cl} \times$ Salts } \\
\hline $0.31 \times \mathrm{CaCl}_{2}$ & 17.30 & 43.19 & 36.59 & 34.34 & 32.86 \\
\hline $0.45 \times \mathrm{CaCl}_{2}$ & 11.76 & 34.42 & 45.25 & 43.14 & 33.64 \\
\hline $0.59 \times \mathrm{CaCl}_{2}$ & 15.10 & 39.39 & 49.90 & 44.20 & 37.15 \\
\hline $0.73 \times \mathrm{CaCl}_{2}$ & 14.84 & 48.12 & 67.40 & 24.21 & 38.64 \\
\hline $0.31 \times \mathrm{NH}_{4} \mathrm{Cl}$ & 14.40 & 32.56 & 30.55 & 30.22 & 26.93 \\
\hline $0.45 \times \mathrm{NH}_{4} \mathrm{Cl}$ & 16.94 & 36.32 & 43.35 & 38.82 & 33.86 \\
\hline $0.59 \times \mathrm{NH}_{4} \mathrm{Cl}$ & 15.36 & 33.71 & 43.84 & 37.73 & 32.66 \\
\hline $0.73 \times \mathrm{NH}_{4} \mathrm{Cl}$ & 11.68 & 24.02 & 42.84 & 45.87 & 31.10 \\
\hline RMSE & 0.298 & 1.113 & 1.291 & 1.675 & 0.567 \\
\hline ANOVA & \multicolumn{5}{|c|}{----------------------- Probability ------'----------- } \\
\hline $\mathrm{Cl}$ & 0.04 & 0.400 & $\leq 0.001$ & 0.058 & $\leq 0.001$ \\
\hline $\mathrm{Cl}_{\mathrm{L}}$ & $\leq 0.001$ & 0.375 & $\leq 0.001$ & 0.273 & $\leq 0.001$ \\
\hline $\mathrm{Cl}_{\mathrm{Q}}$ & $\leq 0.001$ & $\leq 0.001$ & $\leq 0.001$ & $\leq 0.001$ & 0.011 \\
\hline $\mathrm{Cl}_{\mathrm{C}}$ & $\leq 0.001$ & 0.263 & 0.367 & 0.708 & 0.042 \\
\hline Salt & 0.636 & $\leq 0.001$ & $\leq 0.001$ & 0.317 & $\leq 0.001$ \\
\hline Salt $\times \mathrm{Cl}$ & 0.058 & 0.006 & 0.001 & 0.003 & 0.077 \\
\hline
\end{tabular}

$\mathrm{Cl}_{\mathrm{L},} \mathrm{Cl}_{\mathrm{Q}}$ and $\mathrm{Cl}_{\mathrm{C}}$ are linear, quadratic and cubic terms for $\mathrm{Cl}$, respectively $(\mathrm{df}=24)$.

age of the birds, regional production difference and various environmental factors (Patterson et al., 1998). In the present study, the negative effects of higher $\mathrm{dCl}$ are mainly attributed to its corresponding cation i.e. $\mathrm{Na}$, the imbalance between these two ions cause excretion of more water in the faeces due to an imbalance of extracellular fluid and abnormal kidney function (Freeman, 1983). It is known that aldosterone plays major role in the retention of $\mathrm{Na}, \mathrm{Cl}$ and water by the kidneys. These factors, in combination, resulted in a profuse body fluid volume that stimulated the release of atrial natriuretic peptide and aggravated the loss of fluid in the urine.

The highest mortality was observed in the highest level of $\mathrm{dCl}(0.73 \%$ or $\mathrm{DEB}=160 \mathrm{mEq} / \mathrm{kg})$ during $\mathrm{d} 34$ to 42 $(\mathrm{p} \leq 0.003$; Table 8$)$. These results are in accordance with the findings of Ahmad et al. (2008) who observed high mortality in the diet having the lowest level of DEB (150 $\mathrm{mEq} / \mathrm{kg}$ ). This indicates that lighter birds can resist a higher $\mathrm{dCl}$ than heavier birds. Mortality remained unaffected in the rest of the experimental phases ( $p>0.05$ ).

In the present study, the blood $\mathrm{pH}$ abated gradually with 
Table 8. Effect of dietary chloride and chloride salts on blood and carcass responses of broilers at the end of the experiment

\begin{tabular}{|c|c|c|c|c|c|c|c|c|}
\hline Item & Blood pH & $\begin{array}{c}\text { Blood } \\
\text { glucose }^{1}\end{array}$ & $\begin{array}{l}\text { Dressing } \\
\text { weight }^{2}\end{array}$ & Breast weight & Thigh weight & $\begin{array}{c}\text { Intestinal } \\
\text { weight }\end{array}$ & Gizzard & Proventriculus \\
\hline \multicolumn{8}{|l|}{ Dietary $\mathrm{Cl}(\%)$} & -------- \\
\hline 0.31 & 7.32 & 171.9 & 55.96 & 39.55 & 44.83 & 61.13 & 2.91 & 0.53 \\
\hline 0.45 & 7.30 & 177.7 & 55.07 & 39.13 & 45.52 & 57.82 & 2.73 & 0.61 \\
\hline 0.59 & 7.29 & 175.5 & 55.74 & 39.36 & 45.09 & 61.01 & 2.82 & 0.50 \\
\hline 0.73 & 7.28 & 178.3 & 56.24 & 40.38 & 44.49 & 60.05 & 2.93 & 0.54 \\
\hline \multicolumn{9}{|l|}{ Salts } \\
\hline $\mathrm{CaCl}_{2}$ & 7.28 & 168.3 & 56.53 & 38.66 & 44.26 & 63.75 & 2.85 & 0.55 \\
\hline $\mathrm{NH}_{4} \mathrm{Cl}$ & 7.32 & 183.4 & 54.97 & 40.55 & 45.71 & 56.25 & 2.84 & 0.54 \\
\hline \multicolumn{9}{|l|}{$\mathrm{Cl} \times$ Salts } \\
\hline $0.31 \times \mathrm{CaCl}_{2}$ & 7.29 & 173.9 & 57.62 & 38.15 & 44.42 & 63.38 & 2.99 & 0.48 \\
\hline $0.45 \times \mathrm{CaCl}_{2}$ & 7.28 & 171.3 & 56.79 & 37.57 & 44.38 & 64.57 & 2.64 & 0.63 \\
\hline $0.59 \times \mathrm{CaCl}_{2}$ & 7.28 & 164.6 & 55.84 & 39.47 & 44.09 & 67.90 & 2.80 & 0.55 \\
\hline $0.73 \times \mathrm{CaCl}_{2}$ & 7.27 & 163.3 & 55.90 & 39.46 & 44.14 & 59.16 & 2.99 & 0.55 \\
\hline $0.31 \times \mathrm{NH}_{4} \mathrm{Cl}$ & 7.35 & 169.8 & 54.30 & 40.94 & 45.24 & 58.88 & 2.83 & 0.59 \\
\hline $0.45 \times \mathrm{NH}_{4} \mathrm{Cl}$ & 7.32 & 184.0 & 53.34 & 40.68 & 46.66 & 51.06 & 2.82 & 0.59 \\
\hline $0.59 \times \mathrm{NH}_{4} \mathrm{Cl}$ & 7.30 & 186.3 & 55.65 & 39.26 & 46.09 & 54.12 & 2.84 & 0.46 \\
\hline $0.73 \times \mathrm{NH}_{4} \mathrm{Cl}$ & 7.29 & 193.3 & 56.58 & 41.31 & 44.84 & 60.94 & 2.88 & 0.52 \\
\hline RMSE & 0.002 & 3.64 & 0.545 & 0.665 & 0.662 & 2.591 & 0.101 & 0.021 \\
\hline \multicolumn{9}{|c|}{---- Probability - } \\
\hline $\mathrm{Cl}$ & $\leq 0.001$ & 0.066 & 0.340 & 0.891 & 0.673 & 0.069 & 0.061 & 0.02 \\
\hline $\mathrm{Cl}_{\mathrm{L}}$ & $\leq 0.001$ & 0.071 & 0.203 & 0.272 & 0.272 & 0.055 & 0.055 & 0.486 \\
\hline $\mathrm{Cl}_{\mathrm{Q}}$ & 0.051 & 0.099 & 0.078 & 0.833 & 0.833 & 0.855 & 0.393 & 0.056 \\
\hline $\mathrm{Cl}_{\mathrm{C}}$ & 0.069 & 0.055 & 0.250 & 0.576 & 0.576 & 0.165 & 0.121 & 0.111 \\
\hline Salt & $\leq 0.001$ & 0.001 & 0.025 & 0.005 & 0.022 & 0.004 & 0.560 & 0.214 \\
\hline Salt $\times \mathrm{Cl}$ & $\leq 0.001$ & 0.042 & 0.044 & 0.505 & 0.505 & 0.598 & 0.602 & 0.031 \\
\hline
\end{tabular}

${ }^{1} \mathrm{mg} / \mathrm{dL} .{ }^{2} \%$ of live weight (without visceral organs).

$\mathrm{Cl}_{\mathrm{L}}, \mathrm{Cl}_{\mathrm{Q}}$ and $\mathrm{Cl}_{\mathrm{C}}$ are linear, quadratic and cubic terms for $\mathrm{Cl}$, respectively $(\mathrm{df}=24)$.

Number of observations per mean value $=2$ birds $\times 4$ replicates $=8$ birds .

the increasing supplementation of $\mathrm{dCl}(\mathrm{p} \leq 0.001$; Table 9). An acidogenic role of $\mathrm{dCl}$ is well known as reported in a previous study by Murakami et al. (2001). However, a sharp reduction in $\mathrm{pH}$ value in $\mathrm{CaCl}_{2}$ supplemented diets might indicate the reduced absorption of $\mathrm{Ca}$ in the distal part of the intestine and more excretion as $\mathrm{CaCO}_{3}$, so $\mathrm{Cl}$ is retained to reduce blood $\mathrm{pH}$ (Mongin, 1981). It means that the role of $\mathrm{dCl}$ is more sensitive in the case of $\mathrm{CaCl}_{2}$ rather than in $\mathrm{NH}_{4} \mathrm{Cl}$ supplemented diets in order to maintain acid base balance. A profound decrease in blood glucose level was observed in $\mathrm{CaCl}_{2}$ supplemented diets compared to $\mathrm{NH}_{4} \mathrm{Cl}$ supplemented diets in the present study $(\mathrm{p} \leq 0.001)$. At the highest level of $\mathrm{dCl}$ (i.e. $0.73 \%$ ), $\mathrm{CaCl}_{2}$ diets showed a lower glucose level while $\mathrm{NH}_{4} \mathrm{Cl}$ diets showed a higher glucose level $(p \leq 0.04)$. Ahmad et al. (2005) also found reduced blood glucose in $\mathrm{CaCl}_{2}$ supplemented diets when compared with other ionic salts. A better glucose level overall depicts a better health status, however it is clear from the present study that the bird maintains its acid base balance at the cost of better health and growth.

The $\mathrm{CaCl}_{2}$ supplemented diets proved to have a positive effect on dressing percentage (DP) when compared with $\mathrm{NH}_{4} \mathrm{Cl}$ supplemented diets $\left(\mathrm{p} \leq 0.02\right.$; Table 9). The $\mathrm{CaCl}_{2}$ supplemented diets showed highest DP (i.e. 57.62\%) while $\mathrm{NH}_{4} \mathrm{Cl}$ showed lowest DP (i.e. $56.58 \%$ ) at $0.31 \% \mathrm{dCl}$ in the present study $(\mathrm{p} \leq 0.04)$. This increase in DP is evident from the higher intestinal weight, which is the indication of better gut health in $\mathrm{CaCl}_{2}$ supplemented diets in the present study. Moreover, the larger size of the proventriculus and gizzard (however numerically) may have improved the digestive capacity which resulted in higher DP in $\mathrm{CaCl}_{2}$ supplemented diets. Interestingly, the breast $(\mathrm{p} \leq 0.001)$ and thigh $(\mathrm{p} \leq 0.001)$ meat (\% of dressed weight) was found higher when $\mathrm{CaCl}_{2}$ was replaced with $\mathrm{NH}_{4} \mathrm{Cl}$ in the experimental diets. Ahmad et al. (2005) also found higher breast meat yields in $\mathrm{NH}_{4} \mathrm{Cl}$ supplemented groups when comparing with other ionic salts. However, it is still unclear why DP has no relationship with breast and thigh meat yields. The data of 
Table 9. Effect of dietary chloride and chloride salts on plasma mineral chemistry of broilers at the end of the experiment

\begin{tabular}{|c|c|c|c|c|c|c|c|}
\hline Item & $\mathrm{Na}$ & $\mathrm{K}$ & $\mathrm{Cl}$ & $\mathrm{Ca}$ & $\mathrm{P}$ & $\mathrm{Mg}$ & $\mathrm{HCO}_{3}$ \\
\hline & --- & ------ & --- & 1/L ----. & ------- & ------- & ---------- \\
\hline \multicolumn{8}{|l|}{ Dietary $\mathrm{Cl}(\%)$} \\
\hline 0.31 & 138 & 3.08 & 107 & 2.46 & 3.11 & 1.09 & 33.0 \\
\hline 0.45 & 136 & 3.05 & 109 & 2.31 & 2.92 & 1.09 & 32.4 \\
\hline 0.59 & 135 & 3.06 & 111 & 2.04 & 2.99 & 1.18 & 31.9 \\
\hline 0.73 & 136 & 3.05 & 112 & 2.09 & 3.12 & 1.08 & 31.4 \\
\hline \multicolumn{8}{|l|}{ Salts } \\
\hline $\mathrm{CaCl}_{2}$ & 134 & 3.06 & 110 & 2.40 & 3.03 & 1.13 & 31.9 \\
\hline $\mathrm{NH}_{4} \mathrm{Cl}$ & 138 & 3.07 & 109 & 2.05 & 3.04 & 1.09 & 32.4 \\
\hline \multicolumn{8}{|l|}{$\mathrm{Cl} \times$ Salts } \\
\hline $0.31 \times \mathrm{CaCl}_{2}$ & 138 & 3.08 & 108 & 2.90 & 3.09 & 1.20 & 32.7 \\
\hline $0.45 \times \mathrm{CaCl}_{2}$ & 133 & 3.05 & 109 & 2.50 & 2.88 & 1.01 & 32.2 \\
\hline $0.59 \times \mathrm{CaCl}_{2}$ & 132 & 3.05 & 111 & 2.09 & 2.89 & 1.27 & 31.6 \\
\hline $0.73 \times \mathrm{CaCl}_{2}$ & 135 & 3.05 & 112 & 2.12 & 3.26 & 1.04 & 31.1 \\
\hline $0.31 \times \mathrm{NH}_{4} \mathrm{Cl}$ & 138 & 3.09 & 106 & 2.02 & 3.13 & 0.98 & 33.2 \\
\hline $0.45 \times \mathrm{NH}_{4} \mathrm{Cl}$ & 139 & 3.06 & 108 & 2.12 & 2.97 & 1.16 & 32.6 \\
\hline $0.59 \times \mathrm{NH}_{4} \mathrm{Cl}$ & 138 & 3.08 & 110 & 2.00 & 3.09 & 1.09 & 32.2 \\
\hline $0.73 \times \mathrm{NH}_{4} \mathrm{Cl}$ & 138 & 3.05 & 112 & 2.06 & 2.97 & 1.12 & 31.7 \\
\hline RMSE & 0.3 & 0.006 & 0.3 & 0.091 & 0.099 & 0.052 & 0.07 \\
\hline \multicolumn{8}{|c|}{ Probability } \\
\hline $\mathrm{Cl}$ & 0.059 & 0.060 & 0.088 & 0.071 & 0.349 & 0.114 & 0.132 \\
\hline $\mathrm{Cl}_{\mathrm{L}}$ & 0.005 & 0.001 & $\leq 0.001$ & 0.003 & 0.334 & 0.349 & $\leq 0.001$ \\
\hline $\mathrm{Cl}_{\mathrm{Q}}$ & 0.001 & 0.112 & 0.041 & 0.129 & 0.562 & 0.099 & 0.092 \\
\hline $\mathrm{Cl}_{\mathrm{C}}$ & 0.061 & 0.055 & 0.059 & 0.031 & 0.443 & 0.322 & 0.058 \\
\hline Salt & $\leq 0.001$ & 0.235 & 0.001 & 0.001 & 0.763 & 0.110 & $\leq 0.001$ \\
\hline Salt $\times C l$ & 0.001 & 0.093 & 0.069 & 0.003 & 0.818 & 0.211 & 0.062 \\
\hline
\end{tabular}

$\mathrm{Cl}_{\mathrm{L}}, \mathrm{Cl}_{\mathrm{Q}}$ and $\mathrm{Cl}_{\mathrm{C}}$ are linear, quadratic and cubic terms for $\mathrm{Cl}$, respectively $(\mathrm{df}=24)$.

Number of observations per mean value $=2$ birds $\times 4$ replicates $=8$ birds.

body organs have been omitted as they are confusing the growth results.

The supplementation of $\mathrm{dCl}$ affected the plasma mineral chemistry of broilers as shown in Table 10. The higher plasma $\mathrm{Na}^{+}$and $\mathrm{HCO}_{3}^{-}$and lower $\mathrm{Cl}^{-}$and $\mathrm{Ca}^{++}$were observed in $\mathrm{NH}_{4} \mathrm{Cl}$ supplemented diets $(\mathrm{p} \leq 0.001)$. The increase in $\mathrm{HCO}_{3}{ }^{-}$concentration is associated with a decrease in serum $\mathrm{Cl}^{-}$and an increase in the blood $\mathrm{pH}$ (Hurwitz et al., 1973; Ahmad and Sarwar, 2006). The utilization of $\mathrm{Ca}$ is exacerbated with metabolic acidosis, which is reflected from high urinary $\mathrm{Ca}$ in rats when diets were supplemented with $\mathrm{NH}_{4} \mathrm{Cl}$ (Bushinsky et al., 1982). A quadratic response in plasma $\mathrm{Na}^{+}(\mathrm{p} \leq 0.001)$ and $\mathrm{Cl}^{-}$ $(\mathrm{p} \leq 0.04)$ was noted with increasing level of $\mathrm{dCl}$ while plasma $\mathrm{K}^{+}(\mathrm{p} \leq 0.001), \mathrm{Ca}^{++}(\mathrm{p} \leq 0.003)$, and $\mathrm{HCO}_{3}{ }^{-}(\mathrm{p} \leq 0.001)$ were linearly decreased with increasing supplementation of $\mathrm{dCl}$ in the present study. Plasma $\mathrm{Cl}^{-}$tended to be greater in birds receiving high levels of $\mathrm{dCl}$ and the electrolyte concentration in plasma is the reflection of the respective supplemental electrolyte in the diet (Kim et al., 1989; Ahmad et al., 2005).

\section{CONCLUSION}

It is inferred from the present study that a higher concentration of dietary chloride is required for feed intake; nevertheless, the lower levels are sufficient to sustain BWG and FG with increasing age. The $\mathrm{NH}_{4} \mathrm{Cl}$ supplemented diets ameliorated breast and thigh meat yields and the overall energy balance (glucose). It would be useful to test higher concentrations of dietary chloride with changing sodium and potassium ions within a constant electrolyte balance.

\section{ACKNOWLEDGEMENTS}

The present experiment was conducted and sponsored by the Research Model Broiler Unit, Poultry Research and Training Center, Department of Poultry Production, University of Veterinary and Animal Sciences, Ravi Campus, Lahore, Pakistan. The Higher Education Commission (HEC), Islamabad, Pakistan under the program 'Indigenous PhD Fellowship Program (5000 Fellowships) Batch-V' provided with the funding for chemical analyses of diet and blood. The contribution of Zulfiqar Ali (Ex- 
Nutritional Consultant, Big Feeds (Pvt.) Ltd., Lahore, Pakistan) in experimental diets preparation and analyses is highly appreciated. The authors also express gratitude to Rural Development Administration (RDA, Republic of Korea) for bearing the publication charges of this manuscript.

\section{REFERENCES}

Ahmad, T., M. Sarwar, M. U. Nisa, A. U. Haq and Z. U. Hasan. 2005. Influence of varying sources of dietary electrolytes on the performance of broilers reared in a high temperature environment. Anim. Feed Sci. Technol. 120:277-298.

Ahmad, T. and M. Sarwar. 2006. Dietary electrolyte balance: Implications in heat stressed broilers. World's Poult. Sci. J. 62:638-653.

Ahmad, T., T. Mushtaq, M. A. Khan, M. E. Babar, M. Yousaf, Z. U. Hassan and Z. Kamran. 2008. Influence of varying dietary electrolyte balance on broiler performance under tropical summer conditions. J. Anim. Phys. Anim. Nutr. 93:613-621.

AOAC. 2005. Official methods of analysis. 18th edn. Association of Official Analytical Chemists, Gaithersburg, MD, USA.

Belay, T. and R. G. Teeter. 1993. Broiler water balance and thermo-balance during thermo-neutral and high ambient temperature exposure. Poult. Sci. 72:116-124.

Borges, S. A. 1997. Suplementacao de cloreto de potassio e bicarbinato de sodio para frangos de corte durante o verao. Dissertacao de mestrado, UNESP, Jaboticabal.

Borges, S. A., A. V. Fisher da Silva, A. D. A. Meira, T. Moura, A. Maiorka and A. Ostrensky. 2004a. Electrolyte balance in broiler growing diets. Int. J. Poult Sci. 3:623-628.

Borges, S. A., A. V. Fisher da Silva, A. Majorka, D. M. Hooge and K. R. Cummings. 2004b. Physiological responses of broiler chickens to heat stress and dietary electrolyte balance (sodium plus potassium minus chloride, milliequivalents per kilogram). Poult. Sci. 83:1551-1558.

Borges, S. A., A. V. Fischer da Silva, J. Ariki, D. M. Hooge and K. R. Cummings. 2003a. Dietary electrolyte balance for broiler chickens under moderately high ambient temperatures and relative humidities. Poult. Sci. 82:301-308.

Borges, S. A., A. V. Fischer da Silva, J. Ariki, D. M. Hooge and K. R. Cummings. 2003b. Dietary electrolyte balance for broiler chickens exposed to thermoneutral or heat-stress environments. Poult. Sci. 82:482-435.

Branton, S. L., F. N. Reece and J. W. Deaton. 1986. Use of ammonia chloride and sodium bicarbonate in acute heat exposure of broilers. Poult. Sci. 64:1659.

Bushinsky, D. A., M. J. Fauns, A. B. Schneider, P. K. Sen, L. M. Sherwood and F. L. Coe. 1982. Effect of pH on bone calcium and proton fluxes in vitro. Am. J. Physiol. 245:F204-209.

Chiba, L. I. 2009. Water and Electrolytes (\& Iodine), Sec. 4. Animal Nutrition Handbook. 2nd rev. edn. Auburn Univ. Press, AL.

Dozier, W. A. III., M. Czarick, M. P. Lacy and B. D. Fairchild. 2002. Monitoring water consumption on commercial broiler farms: Evaluation tool to assess flock performance. Poult. Sci. 81 (Suppl. 1):154.
El-Deek, A. A., M. S. El-Deen, S. M. Hamdy, M. A. Asar, H. M. Yakout and Y. A. Attia. 2010. Effect of different dietary levels of $\mathrm{NaCl}$ and $\mathrm{KCl}$ on performance of broiler chicks fed plant diets. Egypt. Poult. Sci. 29:907-921.

Freeman, B. M. 1983. Physiology and biochemistry of the domestic fowl. Academic Press Inc., London, UK.

Han, Y. and D. H. Baker. 1994. Digestible lysine requirement of male and female broiler chicks during the period three to six weeks post-hatching. Poult. Sci. 73:1739-1745.

Hayat, J., D. Balnave and J. Brake. 1999. Sodium bicarbonate and potassium supplements for broilers can cause poor performance at high temperature. Br. Poult. Sci. 40:411-418.

Hurwitz, S., I. Cohen, A. Bar and S. Bornstein. 1973. Sodium and chloride requirements of the chick: Relationship to acid-base balance. Poult. Sci. 52:903-909.

Kim, H. W., I. K. Han and Y. J. Choi. 1989. Effects of lysine level and $\mathrm{Na}+\mathrm{K}-\mathrm{Cl}$ ratio on lysine-arginine antagonism, blood $\mathrm{pH}$, blood acid-base parameters and growth performance in broiler chicks. Asian Australas. J. Anim. Sci. 2:7-16.

Lacroix, R. L., D. R. Keeney and L. M. Welsh. 1970. Potentiometric titration of chloride in plant tissue extracts using the chloride ion electrode. Commun. Soil Sci. Plant Anal. $1: 1-6$.

Mongin, P. and B. Sauveur. 1974. Voluntary food and calcium intake by the laying hen. Br. Poult. Sci. 15:349-359.

Mongin, P. 1980. Electrolytes in nutrition. A review of basic principles and practical applications in poultry and swine. In: Proceedings of 3rd Annual International Minerals Conference, Orlando, FL. pp. 1.

Mongin, P. 1981. Recent advances in dietary cation-anion balance: Applications in poultry. Proc. Nutr. Soc. 40:285-294. doi:10.1079/PNS19810045.

Murakami, A. E., E. A. Saleh, J. A. England, D. A. Dickey, S. E. Watkins and P. W. Waldroup. 1997. Effect of level and source of sodium on performance of male broilers up to 56 days. J. Appl. Poult. Res. 6:128-136.

Murakami, A. E., E. O. O. Rondon, E. N. Martins, M. S. Pereira and C. Scapinello. 2001. Sodium and chloride requirements of growing broiler chickens (twenty-one to forty-two days of age) fed corn-soybean diets. Poult. Sci. 80:289-294.

Murakami, A. E., M. I. Sakamoto, J. R. G. Franco, E. N. Martins and E. O. O. Rondon. 2003. Requirements of sodium and chloride by Leghorn laying hens. J. Appl. Poult. Res. 12:217221.

Mushtaq, T., M. A. Mirza, M. Athar, D. M. Hooge, T. Ahmad, G. Ahmad, M. M. H. Mushtaq and U. Noreen. 2007. Dietary sodium and chloride for twenty-nine to forty-two-day-old broiler chickens at constant electrolyte balance under subtropical summer conditions. J. Appl. Poult. Res.16:161-170.

Mushtaq, T., M. Sarwar, H. Nawaz, M. A. Mirza and T. Ahmad. 2005. Effect and interactions of dietary sodium and chloride on broiler starter performance (hatching to twenty-eight days of age) under subtropical summer conditions. Poult. Sci. 84:17161722.

National Research Council. 1994. Nutrient requirements of poultry. 9th revised edn, National Academic Press, Washington, DC, USA.

Oliveira, J. E., L. F. T. Albino, H. S. Rostagno, S. E. Pa'ez and D. 
C. O. Carvalho. 2005. Dietary levels of potassium for broiler chickens. Braz. J. Poult. Sci. 7:33-37.

Patterson, P. H., E. S. Lorenz and W. D. Weaver, Jr. 1998. Litter production and nutrients from commercial broiler chickens. J. Appl. Poult. Res. 7:247-252.

Pesti, G. M., H. Cervantes, R. I. Bakalli, K. W. Bafundo and M. N. Garcia. 1999. Studies on semduramicin and nutritional responses. 3. Electrolyte balance. Poult. Sci. 78:1552-1560.

Singleton, R. 2004. Hot weather broiler and breeder management Asian Poult. Mag., September Issue. pp. 26-29.
Smith, M. O. and R. G. Teeter. 1989. Effects of sodium and potassium salts on gain, water consumption and body temperature of 4 to 7 week old heat stressed broilers. Nutr. Rep. Int. 40:161-169.

Socha, M. T., S. M. Ensley, D. J. Tomlinson and B. Johnson. 2002. Variability of water consumption and potential impact on animal performance. In: Proceedings of California Animal Nutrition Conference, Fresno, CA. pp. 81-91.

Teeter, R. G. and M. O. Smith. 1986. High chronic ambient temperature stress effects on broiler acid base balance and their response to supplemental ammonium chloride, potassium chloride and potassium carbonate. Poult. Sci. 65:1777-1781. 